\title{
Proposed Solution of e-Waste Management
}

\author{
Shagun, Ashwani Kush, and Anupam Arora
}

\begin{abstract}
Electronic waste may be defined as discarded computers, office electronic equipment, entertainment device electronics, mobile phones, television sets and refrigerators. This definition includes used electronics which are destined for reuse, resale, salvage, recycling, or disposal. Because loads of surplus electronics are frequently commingled (good, recyclable, and non-recyclable), several public policy advocates apply the term "e-waste" broadly to all surplus electronics. Rapid changes in technology, changes in media (tapes, software, MP3), falling prices, and planned obsolescence have resulted in a fast-growing surplus of electronic waste around the globe. This paper presents an overview of the problem and suggests some concrete solutions to tackle the issue.
\end{abstract}

Index Terms-E-waste, media, electronics, computer.

\section{INTRODUCTION}

E-waste is a popular informal name for electronic products nearing the end of their useful life. Anything that runs on electricity/battery or has wire and completed its life is e-waste [1] [2]. Electronic waste may be defined as discarded computers, office electronic equipment, entertainment device electronics, mobile phones, television sets and refrigerators. e-wastes are considered dangerous, as certain components of some electronic products contain materials that are hazardous, depending on their condition and density. The hazardous content of these materials pose a threat to human health and environment.

Discarded computers, televisions, VCRs, stereos, copiers, fax machines, electric lamps, cell phones, audio equipment and batteries if improperly disposed can leach lead and other substances into soil and groundwater.

Electronic waste, e-waste, e-scrap, or Waste Electrical and Electronic Equipment (W.E.E.E) [3] [4] describes discarded electrical or electronic devices. There is a lack of consensus as to whether the term should apply to resale, reuse, and refurbishing industries, or only to product that cannot be used for its intended purpose. Informal processing of electronic waste in developing countries may cause serious health and pollution problems, though these countries are also most

Manuscript received February 9, 2013; revised March 19, 2013. The paper is joint work of NIT Kurukshetra and Kurukshetra University Kurukshetra India.

Shagun is with the National Institute of Technology Kurukshetra India She is student of B.Tech in computer engineering. (e-mail: shagun_kush@ yahoo.in).

Ashwani Kush is with in computer science at university college Kurukshetra University India. He is actively involved in research and has more than 90 research papers to his credit. He is member of IACSIT (e-mail: akush20@gmail.com, akush@kuk.ac.in).

Anupam Arora is with in Physics and is actively involved in e-waste product management. He has done Ph.D from Kururkshetra University India and has been working for more than 20 years (e-mail: anupamhead@gmail.com). likely to reuse and repair electronics. Some of categories include: Mobile Phones, Computers, ,Servers, Telecom, TV, Calculators, Audio, Scanners, Printers, Air Conditioner, Microwave, Washing Machine, Cartridges, Military electronic, Mother board, Alarm, Sirens, Automobile Catalytic Converter, Sensor, CD, Security Device etc.

Industrial revolution followed by the advances in information technology during the last century has radically changed people's lifestyle. Although this development has helped the human race, mismanagement has led to new problems of contamination and pollution. The technical prowess acquired during the last century has posed a new challenge in the management of wastes. For example, personal computers (PCs) contain certain components, which are highly toxic, such as chlorinated and brominated substances, toxic gases, toxic metals, biologically active materials, acids, plastics and plastic additives. The hazardous contents [5] [6] of these materials pose an environmental and health threat. Thus proper management is necessary while disposing or recycling e-wastes. The paper highlights these issues and pose some concrete suggestions.

\section{RECENT STUDIES}

Debate continues over the distinction between "commodity" and "waste" electronics definitions. Some exporters are accused of deliberately leaving difficult-to-recycle, obsolete, or non-repairable equipment mixed in loads of working equipment. Protectionists may broaden the definition of "waste" electronics in order to protect domestic markets from working secondary equipment. The high value of the computer recycling subset of electronic waste can help pay the cost of transportation for a larger number of worthless pieces than can be achieved with display devices, which have less scrap value. In A 2011 report, "Ghana E-Waste Country Assessment", found that of 215,000 tons of electronics imported to Ghana, 30\% were brand new and $70 \%$ were used. Of the used product, the study concluded that $15 \%$ was not reused and was scrapped or discarded.

1) USA discards 30 million computers each year and 100 million phones are disposed of in Europe each year [5]

2) The Environmental Protection Agency estimates that only $15-20 \%$ of e-waste is recycled, the rest of these electronics go directly into landfills and incinerators [5]

3) An estimated 50 million tons of E-waste are produced each year. [6] [7]

4) The United States is the world leader in producing electronic waste, tossing away about 3 million tons each year [8] 
5) China already produces about 2.3 million tons (2010 estimate) domestically, second only to the United States [9] [10].

6) Legal framework, proper collection system missing.

7) Imports regularly coming to the recycling markets.

\section{INDIAN SCENARIO}

IT and telecom are two fastest growing industries in the country. India, by 2011, has achieved a PC penetration of 95 per 1000 from the 14 per 1000 in 2008 . At present, India has 95 million one of the most threatening substances is lead, of which only 5 percent is recycled in India [11]. Indians will not junk their mobiles, but pass them on to a new low-end user who will, in turn, junk them in the flea market from where the instruments make their way to the Kabadiwallas. Major issues related to Indian scenario are:

- India's hospitals to see patients with 10 times the expected level of lead in their blood

- In India, a water sample revealed levels of lead 190 times as high as the drinking water standard set by the World Health Organization.

- Thousands of children throughout the India are attending schools that were built on or near toxic waste sites, with increased risk of developing asthma, cancer, learning disorders and other diseases linked to environmental pollutants.

- 1-20 kg per person/p.a and growing at 3 times faster than the municipal waste

- Over 200 million current mobile users

- Preliminary estimates suggest that total WEEE generation in India is approximately $1,46,000$ tonnes per year.

- 20 million electronic household appliances including TV, washing machines, PCs etc) and 70 million cell phones reach end-of-life every year. Memory devices, MP3 players, iPods, ipads etc. are the newer additions.

- About $70 \%$ of the heavy metals (mercury and cadmium) and $40 \%$ lead, in landfills in India come from e-waste

- $22 \%$ of the yearly world consumption of mercury is used in electronics manufacture

- More of acid content flow into the land contaminating the soil and land value.

- About 70 percent, of heavy metals in India landfills comes from E-Waste.

- World's $80 \%$ population live in areas of cell phone reception

- Indians upgrade or exchange their cell phones every 18 months, meaning there are approximately 16 million unused mobile phones stashed away at home or in the office

- Average working life of a mobile phone is 7 years but worldwide the average consumer changes their mobile every 11 months.

E-waste is exported to India because of major reasons as:

1) Cheap labour : rates are approximately

$$
\begin{aligned}
& \text { US - \$ } 30 / \text { computer } \\
& \text { India - \$2 } 2 / \text { computer } \\
& \text { Saving - \$28/ computer }
\end{aligned}
$$

2) Weak environmental laws

3) Excess dumping of CRT tubes due to the ramp walk of flat screen monitors

\begin{tabular}{|c|c|c|}
\hline Source of e-wastes & Constituent & Health effects \\
\hline $\begin{array}{l}\text { Solder in printed } \\
\text { circuit boards, glass } \\
\text { panels and gaskets in } \\
\text { computer monitors }\end{array}$ & Lead (PB) & $\begin{array}{l}\text { Damage to central and } \\
\text { peripheral nervous systems, } \\
\text { blood systems and kidney } \\
\text { damage. } \\
\text { - Affects brain development of } \\
\text { children. }\end{array}$ \\
\hline $\begin{array}{l}\text { Chip resistors and } \\
\text { semiconductors }\end{array}$ & Cadmium (CD) & $\begin{array}{l}\text { Toxic irreversible effects on } \\
\text { human health. } \\
\text { - Accumulates in kidney and } \\
\text { liver. } \\
\text { - Causes neural damage. } \\
\text { - Teratogenic. }\end{array}$ \\
\hline $\begin{array}{l}\text { Relays and switches, } \\
\text { printed circuit } \\
\text { boards }\end{array}$ & Mercury (Hg) & $\begin{array}{l}\text { - } \quad \text { Chronic damage to the brain. } \\
\text { Respiratory and skin } \\
\text { disorders due to } \\
\text { bioaccumulation in fishes. }\end{array}$ \\
\hline $\begin{array}{l}\text { Corrosion protection } \\
\text { of untreated and } \\
\text { galvanized steel } \\
\text { plates, hardner for } \\
\text { steel housings }\end{array}$ & $\begin{array}{l}\text { Hexavalent } \\
\text { chromium }(\mathrm{Cr}) \\
\text { VI }\end{array}$ & $\begin{array}{l}\text { - Asthmatic bronchitis. } \\
\text { - DNA damage. }\end{array}$ \\
\hline $\begin{array}{l}\text { Cabling and } \\
\text { computer housing }\end{array}$ & $\begin{array}{l}\text { Plastics } \\
\text { including PVC }\end{array}$ & 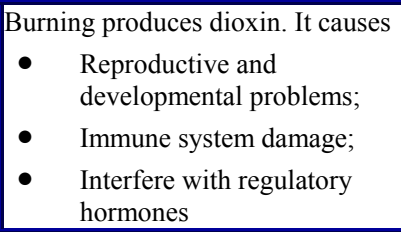 \\
\hline $\begin{array}{l}\text { Plastic housing of } \\
\text { electronic } \\
\text { equipments and } \\
\text { circuit boards. }\end{array}$ & $\begin{array}{l}\text { Brominated } \\
\text { flame retardants } \\
(\mathrm{BFR})\end{array}$ & $\begin{array}{l}\text { - Disrupts endocrine } \\
\text { system functions }\end{array}$ \\
\hline Front panel of CRTs & Barium $(\mathrm{Ba})$ & $\begin{array}{l}\text { Short term exposure causes: } \\
\text { Muscle weakness; } \\
\text { Damage to heart, liver and } \\
\text { spleen. }\end{array}$ \\
\hline Motherboard & Beryllium (Be) & $\begin{array}{l}\text { - Carcinogenic (lung cancer) } \\
\text { Inhalation of fumes and dust. } \\
\text { Causes chronic beryllium } \\
\text { disease or beryllicosis. } \\
\text { - } \quad \text { Skin diseases such as warts. }\end{array}$ \\
\hline $\begin{array}{l}\text { Av PC of App } \\
31 \mathrm{~kg} \text { wt contains }\end{array}$ & & $\begin{array}{l}\text { Two million obsolete Pcs } \\
\text { would mean }\end{array}$ \\
\hline $7.24 \mathrm{~kg}$ & Plastics & $14,427,000 \mathrm{~kg}$ \\
\hline $1.98 \mathrm{Kg}$ & Lead & $3.962,700 \mathrm{~kg}$ \\
\hline $0.693 \mathrm{~g}$ & $\begin{array}{ll} & \text { Mercur } \\
\mathrm{y} & \\
\end{array}$ & $1,386 \mathrm{~kg}$ \\
\hline $0.4095 \mathrm{~g}$ & c Arseni & $819 \mathrm{~kg}$ \\
\hline $2.961 \mathrm{~g}$ & $\begin{array}{l}\text { Cadmi } \\
\text { um }\end{array}$ & $5,922 \mathrm{~kg}$ \\
\hline $1.98 \mathrm{~g}$ & $\begin{array}{l}\text { Chromi } \\
\text { um }\end{array}$ & $3,969 \mathrm{~kg}$ \\
\hline $9.92 \mathrm{~g}$ & Barium & $19,845 \mathrm{~kg}$ \\
\hline $4.94 \mathrm{~g}$ & $\begin{array}{l}\text { Berylli } \\
\text { um }\end{array}$ & $9,891 \mathrm{~kg}$ \\
\hline
\end{tabular}

4) Driven by the potential for corporate profits

TABLE I: EFFECTS OF E-WASTE CONSTITUENT ON HEALTH

\section{E-Waste Health Problems and Solutions}

E-waste is very valuable as it (a) recover precious metals (b) recover plastic etc. Three categories of WEEE account for almost $90 \%$ of the generation: 

Large Household appliances:
$42.1 \%$
Information and communications:
Technology equipment
Consumer Electronics:

Inhalation of open fire emissions can trigger asthma attacks, respiratory infections, and cause other problems such as coughing, wheezing, chest pain, and eye irritation [12]. Example: burning PVC releases hydrogen chloride, which on inhalation mixes with water in the lungs to form hydrochloric acid. This can lead to corrosion of the lung tissues, and several respiratory complications. Table I gives a view of e-waste health hazardous.

\section{Proposed SOLUtions}

The Key Players in e-waste are 1) Consumers as in (a) Office and (b) Domestic, 2) Scrap Dealers and 3) Recyclers Existing Laws are:

- Tran's boundary movement of e-waste covered under the Basel convention.

- India ratified the convention in 1992.

- Waste importers exploit such gaps as listed in the convention.

- Allowed to import against a license.

- Covered under the "Hazardous Waste Amended Rules, 2003" in List A and B of Schedule 3. [6]

- The Rule is inadequate to handle generation, transportation and disposal of this complex waste

- Regulators unable to monitor and regulate the informal sector.

Proposed solutions can be:

- Ban on total imports of e- waste.

- Domestic legal framework to address these gaps in import of E Waste

- Need to address safe disposal of domestic waste.

- Tie recycling in with take-back product

- The Framework should address the issue of $\mathrm{E}$ waste imports for reuse and recycling.

- Attract investment in this sector

- Link up activities of informal sector with formal sector

- $\quad$ Provide for appropriate framework for processes

- Promote adequate ESM technologies for recycling

- Incorporate precautionary principles and polluter pays

- $\quad$ Adopt Consultative process

- $\quad$ Picked over Junk, Obsolete and burnt

- Insist on domestic processing

- Then make sure the company you select has capacity to handle either type of E-Scrap.

- Promote recycling units to ease process and to encourage generators to have proper e-waste disposal

- Impart training to generators on e-waste handling

- Awareness program on recycling

- Fix duties and responsibilities to recyclers

- Tax incentives for scrap dealers

- Reward and reprimand schemes for performance and non-compliance of e-waste management
- To make recycling business viable one

- Government should encroach legal import of e-waste

- Should subsidize recyling and disposal industry

- Incentive schemes for garbage collectors, general public

- Disposal fee from manufacturers and consumers

Some organizations already helping the cause are: www.mineralpolicy.org, www.mpi.org.au, www.USGS.gov, www.moles.org, www.ban.org, www.copper.org, www.antigraymarket.org, other links www.retroworks.com

- Over 1,000 parts requests per day via internet parts exchange www10.tradeloop.com

- Contact with over 200 international repair shops via www.exporters.com.sg,www.alibaba.com,

www.globalrecycle.net, www.recycle.net, etc. www.exporters.com/sg

- Sales of parts and refurbishment on ebay.com , www.ebay.com

- $\quad$ Scrap copper, alum, plastic sold directly to end users www.globalrecycle.net

Also some more points that can be considered while buying electronic products are:

- $\quad$ are made with fewer toxic constituents

- use recycled content

- $\quad$ are energy efficient

- $\quad$ are designed for easy upgrading or disassembly

- utilize minimal packaging

- offer leasing or take back options

which have been certified by regulatory authorities. Customers should opt for upgrading their computers or other electronic items to the latest versions rather than buying new equipment's.

\section{REFERENCES}

[1] Handbook of Hazardous Waste Treatment and Disposal, McGraw-Hill Company, M. H. Freemn, USA, 1989.

[2] Toxic Terror: Dumping of Hazardous Wastes in the Third World, Third World Network. ,Malaysia 1991

[3] Ghana e-Waste Country Assessment, Ghana e-Waste Country Assessment. SBC e-Waste Africa Project, [Online]. Available: http://ewasteguide.info/files/Amoyaw-Osei_2011_GreenAd-Empa.pdf

[4] K. Melanie. What is 'e-Waste' \& how can I Get Rid of It. [Online]. Available:

http://www.fourgreensteps.com/infozone/featured/features/what-is-ewaste-a-how-can-i-get-rid-of-it.

[5] US Environmental Protection Agency. [Online]. Available: http://www.epa.gov/epawaste/conserve/materials/ecycling/manage.ht m. Retrieved 2012-03-13.

[6] United Nations News Service 2010 United Nations-DPI/NMD - UN News Service Section. [Online]. Available: http://www.un.org/apps/news/story.asp?NewsID=33845.

[7] P. Nitya. Cash for Laptops Offers 'Green' Solution for Broken or Outdated Computers. [Online]. Available: http:/green.tmcnet.com/topics/green/articles/37567-cash-laptops-offe rs-green-solution-broken-outdated-computers.htm.

[8] C. Terence. America Ships Electronic Waste Overseas [Online]. Available:

http://biz.yahoo.com/ap/071118/exporting_e_waste.html?.v=3.

[9] R. Kahhat and E Williams, "Product or Waste? Importation and End-of-Life Processing of Computers in Peru," Center for Earth Systems Engineering and Management, Arizona State University, published Environmental Science and Technology June 2009. 
[10] CBC News. [Online]. Available: http://www.cbc.ca/mrl3/23745/thenational/archive/ewaste-102208.w $\mathrm{mv}$

[11] CII, "E-waste management," Green Business Opportunities, vol. 12, no. 1, Confederation of Indian Industry, Delhi 2006.,

[12] C. Y. Yuan, H. C Zhang, M. Kenna, G. Korzeniewski, and J. Li, "Experimental studies on cryogenic recycling of printed circuit board," International Journal of Advanced Manufacturing Technology, Vol. 34, 2007, pp. 657-666.

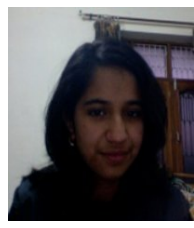

Shagun is currently pursuing $\quad$ B. Tech in computer engineering at National institute of technology Kurukshera India.

She has keen interest in e-waste product management, data structure and algorithms. She has strong passion for research and development.

She is member of computer society of India.

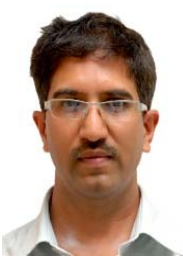

Ashwani Kush is employed as Head and Associate Professor in Department of Computer Science University College, Kurukshetra University, Kurukshetra India. He has done Ph.D. in Computer Sciencee in association with Indian Institute of Technology Kanpur, India and Kurukshetra University, Kurukshetra, India

He has more than 90 research papers to his credit in various International/National Journals and Conferences. He has authored
15 books in computer science for undergraduate and school students. He has more than 20 years of teaching experience.

Dr. Ashwani Kush is professional Member of ACM, IEEE, SCRA, CSI

INDIA and IACSIT Singapore, IAENG Hon Kong. His research interests are in Mobile Ad hoc Networks, E-Governance and Security. Dr. Kush has chaired many sessions in International Conferences in USA and Singapore. $\mathrm{He}$ is also on the panel of eminent resource persons in Computer Science for EDUSAT project, Department of Higher Education, Government of Haryana.

Anupam Arora is the principal and an associate Professor in Physics. He has an extensive teaching and research experience for more than 15 years. His areas of interest are e-waste management, high energy devices. He has authored two books for undergraduate students. Dr Anupam is member of Physics society of India. 